\title{
on_education
}

Journal for Research and Debate

\section{education in the anthropocene: a pragmatic approach}

\author{
Randall Curren and Ellen Metzger
}

\begin{abstract}
Human beings have made a mess of things, both for themselves and for countless multitudes of other life forms that inhabit this planet. There are so many of us, inflicting so much damage on the planetary systems on which we depend, doing so ever more rapidly, on an ever larger scale, with increasingly powerful built systems, that the survival of civilization as we know it can no longer be taken for granted.
\end{abstract}

Human beings have made a mess of things, both for themselves and for countless multitudes of other life forms that inhabit this planet. There are so many of us, inflicting so much damage on the planetary systems on which we depend, doing so ever more rapidly, on an ever larger scale, with increasingly powerful built systems, that the survival of civilization as we know it can no longer be taken for granted.1 Ecosystems are being disrupted, water scarcity is growing more acute, food production in many regions is at risk or already collapsing, and climate refugees are on the move as their lands become uninhabitable (Hammer, 2013; U.S. Department of Defense, 2015).2 Meanwhile, populations of mammals, reptiles, amphibians, fish, and birds have declined by sixty percent in just four decades, and human activities are causing the extinction of tens of thousands of species every year, making this era the sixth mass extinction event discernible in the 4 billion year history of life on this 4.5 billion year old planet (Leakey \& Lewin, 1995; Kolbert, 2015; WWF, 2018).

The prospects for a desirable future will depend on the intelligence and goodwill with which humanity comes to terms with the harsh new reality it is creating. A "deep time" view from the perspective of billions of years of Earth history reveals that we are in uncharted territory, facing a complex, interacting array of systemic action problems that can only be managed through an unprecedented level and duration of well-informed cooperation. 3 It is essential that such cooperation be global but also highly distributed, that attempts to manage the interactions of human, built, and natural systems be adaptive, and that scientists, system managers, and representatives of the public interest collaborate in addressing urgent and fundamental problems. There has been some progress along these dimensions, but climate science is still adjusting to the unexpectedly rapid pace of observed changes, earth system scientists are only beginning to model the interactions between a changing climate system and other systems that are being altered by human activity, and failures of domestic and global civic-mindedness and collective wisdom are inhibiting progress.

The idea that human activities have launched Earth into a new geologic epoch, the Anthropocene, is an attempt to encourage a long view of the coevolution of life and the planet, as well as a long and deeply systemic view going forward.4 It calls for a fundamental rethinking of human-environment relationships (Bauer \& Ellis, 2018) and announces the importance of a long-term, systemic, and collective perspective and standard of judgment for the governance of human affairs - a standard 
that could scarcely be realized without a profound reorientation of education. The long geologic view reveals that the world is not a fixed stage on which we act. Rather, it is a set of densely interacting systems, in which our role has grown so large that it is disrupting the system equilibria on which our existence depends. A near-term example of such disruption is the human assaults on ocean conditions that have allowed fish to flourish and held jellyfish in check for eons. Human activities have not only brought ocean fish populations to the brink of collapse, they have altered ocean temperature, toxicity, and habitat in ways favorable to massive jellyfish blooms - ways favorable to a radical devolution or shift of marine ecology (Gershwin, 2013).

A long geologic view of climate, lifeforms, and the composition of Earth's atmosphere could begin 3.5 billion years ago $(3.5 \mathrm{Ga})$, with the advent of photosynthetic cellular life and ATP-generating bacteria, which provide essential bases for countless subsequent lifeforms. Oxygenating photosynthetic cyanobacteria followed by $3 \mathrm{Ga}$, making possible the Great Oxygenation Event that transformed Earth's atmosphere from one rich in carbon to one rich in oxygen. This caused the extinction of most anaerobic lifeforms and made oxygen-metabolizing lifeforms, such as our own, possible. It also cooled the planet, by removing massive quantities of carbon from the atmosphere in forms laid down as fossil hydrocarbons. The advent of land plants 850 to 630 million years ago (Ma) may have triggered the first glaciation, the first vertebrate lifeforms with bones followed around $485 \mathrm{Ma}$, and mammals appeared around $160 \mathrm{Ma}$. Five mass extinction events are discernible in the fossil record, the first around $400 \mathrm{Ma}$ and the fifth at $66 \mathrm{Ma}$, which enabled mammals to flourish by wiping out large carnivorous reptiles. It then took about 41 million years for deer to evolve from the small mammals that survived that mass extinction event, and another 23 million years for the first mammals of the genus Homo to appear (2 Ma). Anatomically modern deerhunting humans followed about 250,000 years ago, and began leaving Africa and colonizing other continents about 50,000 years ago. They subsequently began unearthing and burning fossil hydrocarbons as fuel, and in the blink of a geologic eye have returned to the atmosphere a quantity of carbon that it took photosynthetic lifeforms a billion or so years to remove from the atmosphere. Human beings' adaptability, ingenuity, and cooperative capacities have enabled them to inhabit, but also disrupt, every corner of the Earth. If we survive, it will be through a repurposing of these same attributes.

An understanding of deep time supplies a crucial framework for understanding human interactions with planetary systems. Yet few college students at even the best universities in the U.S. know this history. If our own experience is any indication, few college students have even a rough conception of the orders of magnitude of the time periods involved or the scale of planetary impact that living things have had. Few have learned much earth science or evolutionary biology in school, in part because the former is neglected in favor of sciences that are more important to college admission, and in part because of widespread cultural resistance to accepting mechanisms of evolution as the explanatory heart of biological science. Little evolutionary science is taught in U.S. schools, and public opinion polling continues to find that about half of all Americans reject evolution and believe human beings were divinely created in their present form about 10,000 years ago. Growing numbers also believe that Earth too was divinely created in essentially its present form at that time. 5 There is similarly pushback against instruction in climate science in some school districts (Hickman, 2011), though public trust of science is generally very high in the U.S. (Jackson, 2018), and a majority of voters in both major parties now agree that government should do more to combat climate change, including through education in "the causes and consequences of global warming, and potential solutions" (Hochschild \& Hochschild, 2018). 
There is thus, even in the highly polarized U.S. context, growing agreement that schools should provide science-based instruction in at least some aspects of the realities of living in the Anthropocene. The basis of this agreement is clearly pragmatic, in the sense that it acknowledges there is a problem that needs to be collectively addressed. The achievement of this much agreement offers some hope of progress in managing problems of sustainability, but it leaves some fundamental questions unresolved. Is environmental education essential to a successful transition to sustainable living? If so, what kind of environmental education? Can the kind of environmental education essential to sustainability be justified to members of the society whose legitimately divergent conceptions of a good life should be protected by ideals of free and equal citizenship and government neutrality?

Is environmental education necessary? We suggested at the outset that the prospects for humanity in the Anthropocene will depend on the intelligence and goodwill with which it comes to terms with complex systemic action problems that can only be managed through well-informed cooperation that is both global and highly distributed. We have defended aspects of this multi-faceted claim at length elsewhere (Curren \& Metzger, 2017), and will limit ourselves to a few summary remarks. The most basic point is that if markets are left to themselves, managing assets in ways expected to be profitable and treating everything else as expendable, there is no reason to think that they will generate and scale up technical innovations of the kind and at the rate needed to avert catastrophic harm to billions of people and other living things. The system may prove to be self-regulating in the sense that the global human population will collapse and its environmental footprint will be forced into alignment with the planet's collapsing ecosystem capacity, but this is no one's idea of how to live sustainably. We argue that an ethically defensible conception of sustainable living would focus on the preservation of biocapacity and opportunity to live well. The evidence suggests that sustainability in this sense will require policy interventions and voluntary limitations of fertility that yield a humanely declining human population.

In the sphere of policy, opportunity-preserving sustainability will require a carbon tax or system of tradeable permits in carbon emissions, to efficiently guide choices away from ones inconsistent with sustainability and to stimulate the right kinds of innovation. Climate stability is only one of nine Planetary Boundaries that must be protected, however, so similar policy instruments will need to be developed and implemented with respect to the others as well.6 In the absence of such price signals, it is simply not possible for individuals to know what changes in their behavior are necessary aspects (the coordination problem) of a collectively sufficient response (the assurance problem).

The pivotal question, then, is whether regulatory interventions and research and education to facilitate innovation would be enough. Must education lead the change in how we live, such as by promoting 'green citizenship'? We think it must, for three reasons.

First, we regard the need for truth and understanding as a fundamental human interest, and epistemic cooperation to secure these goods for everyone as a fundamental matter of justice. Understanding the state of the world as it bears on the significance of one's actions is foundational to living well, and the promotion of such understanding requires institutions of public knowledge and educational institutions that promote the development of intellectual virtues. The point of membership in a cooperative society is to be able to live well, or live better than one could outside of such a society, and the focus of just institutions would accordingly be to provide the developmental (internal) and circumstantial (external) necessities for living well (Curren \& Metzger, 2017, pp. 72-86, pp. 89-123). The developmental foundations of living well include understanding, 
capabilities, intellectual and moral virtues, and associated valuing of things of value. These are arguably the forms of personal attributes that are essential to directing one's life effectively and engaging in the activities of a good life. Relying on this conception of the kind of education children are entitled to as a matter of justice, we argue that children have a right to an education in sustainability that prepares them with the understanding, capabilities, and virtues foundational to living well and participating in environmental governance both globally and in every other civic sphere to which they belong.

Second, an education of this kind is not only every child's right, but also a prerequisite for legitimate environmental governance (Curren \& Metzger, 2017, pp. 46-50; Curren \& Dorn, 2018, pp. 121-132). Imposing such governance primarily by force is neither effective nor just, and an exclusive reliance on top-down centralized governance is much less effective and just than widely distributed cooperation based on common understandings, virtues, and sufficient opportunities (Ostrom, 2010; Ignatieff, 2017). "Government regulation, collective action guided by common norms and understandings, and market mechanisms are less distinct than imagined and must be harmonized to protect opportunity both now and in the future," we argue (Curren \& Metzger, 2017, p. 182). It follows that education in the relevant understanding, norms of cooperation, and related virtues must play a leading role in changing how we live. We have not used the term 'green citizenship', but it's a fair description of the form of education for global environmental cooperation that we propose.

Third, environmental education appears to be instrumentally useful to shifting the political and corporate playing field with respect to sustainability. Public understanding of what is at stake and willingness to take voluntary steps toward living more sustainably may be essential to signaling political leaders that providing leadership on climate and sustainability issues will not end their careers.

What kind of environmental education is necessary? We asserted above that sustainability requires a long-term, systemic, and collective perspective and standard of judgment that is only possible through a profound reorientation of education, but we have so far identified only some basic aspects of the education we think is needed. Here too, we can only touch on the most relevant aspects of the vision of education in sustainability we have detailed and defended elsewhere (Curren \& Metzger, 2017; Metzger \& Curren, 2017: Curren, 2018a, 2018b; Curren \& Metzger, 2018). There are four key ideas in our approach that come together in a form of environmental education that would require a 'profound reorientation'.

The first key idea is that the cultivation of good practical judgement plays a central role in education that equips students to live well (Curren, 2014). Given what we have already said above about the pervasive significance of unsustainability in the conduct of our lives and the prospects for humanity, education in sustainability would be essential and it should be geared to providing an essential basis of understanding and intellectual, ethical, and civic virtues foundational to forming and acting from good judgment. A second key idea is that the systemic nature of sustainability challenges demands an integrated, multi-disciplinary, systems-focused approach (Curren \& Metzger, 2017, pp. 171-176). We noted the significance of a deep geologic perspective in our introductory remarks, and the approach we envision would both include, and go far beyond, systematic instruction in environmental science. A third key idea is that instruction in the ethics of sustainability is essential (Curren \& Metzger, 2017, pp. 53-69, pp. 176-179). We identify principles of sustainability ethics that are entailed by basic ethical requirements of mutual respect and taking care to avoid harming 
others, and we identify related virtues of sustainability. These entail a valuing of nature that can be encouraged by environmental educators through understanding and experience of nature (Ferkany, 2018; Curren \& Metzger, 2018), as well as through education focused on the instrumental value of nature for human well-being. A fourth key idea is that all of these elements should come together in collaborative, civic, project and problem-focused learning (Curren \& Metzger, 2017, p. 175; Curren \& Dorn, 2018, pp. 121-132). All told, this would arguably amount to a profound reorientation of education.7

Can the needed form of environmental education be justified within the constraints of liberal neutrality? Yes. Liberal neutrality, as it is understood within a Rawlsian framework, is intended to protect an aspect of free and equal citizenship, namely the powers to have, revise, and live in accordance with a reasonable conception of a good life. The reasonableness of a conception of a good life is essentially a matter of its compatibility with free and equal citizenship for all members of the society and related fair terms of cooperation. The protections take the form of equal rights and liberties and fair access to the other 'primary goods' that Rawls regards as providing 'all purpose' means to the pursuit of any reasonable conception of a good life. In addition to the fundamental constitutional principles of justice that define fair access, the fair terms of cooperation that Rawls identifies include principles of public reason - the principles that regulate the kinds of values and evidence for factual claims that can legitimately enter into the determination of public policy, especially matters of fundamental constitutional importance. With respect to factual matters within the purview of sciences, the norms of public reason require deference to authoritative scientific judgment, and matters of scientific consensus can be considered in determining what the fundamental principles of justice will be.

Predicating public policy and educational content on sustainability science is quite defensible from this standpoint, even if the empirical claims associated with some 'comprehensive' conceptions of a good life are incompatible with science. There is simply no other feasible basis on which to collectively address the problems we face than to invest in public knowledge and rely on the best evidence regarding empirical matters that we have. To insist that education in science is important to sustainability and that requiring science education is not a violation of liberal neutrality is not, however, to insist that the proper goal of science education is to inculcate belief. The goal we have identified, and others have defended in more detail, is understanding (Laats \& Siegel, 2016). Societies owe children a scientifically sound understanding of the world they must navigate, but they cannot legitimately compel anyone to accept and act on that understanding.

We reject some aspects of the orthodox Rawlsian view, especially with regard to environmental and intergenerational justice, the functions of institutions, and the science of well-being, but we accept its strictures regarding neutrality. The essential point regarding our conception of sustainability ethics is that the principles we identify are entailed by an ethic of respect for persons that is closely associated with Rawls's conception of free and equal citizenship and basic to any freedomrespecting system of law. In other words, these principles of sustainability ethics should be accepted as part of what defines equal opportunity to pursue legitimately diverse conceptions of a good life. The same applies to our associated virtues of sustainability and well-informed instrumental valuing of nature, because the valuing at stake is not prejudicial with respect to any legitimate conception of a good life. It is a valuing of universal external necessities for living well, or something akin to a class of Rawlsian primary goods. With respect to the non-instrumental valuing of nature that understanding and experience of nature may inspire when students receive environmental education, it is no more a violation of liberal neutrality than an education in logic that inspires appreciation of 
and devotion to careful reasoning, an education in cooking that elevates the tastes and inspires a devotion to culinary artistry, or physical education that provides students with a variety of opportunities to fulfill their athletic potential in devotion to gratifying pursuits.

Providing opportunities to experience nature and to engage in ethical inquiry about the value of nature are legitimate means to enabling students to grasp the value of what is in any case conducive to their own future opportunities. Any conception of a good life this may undermine is almost certainly one that unreasonably impairs the opportunities of others. Here we face the fundamental problem with living unsustainably: That the conceptions of a good life we live by cannot all be reasonable as enacted, because the ways we live are collectively violating fundamental requirements of justice with respect to the opportunities of future generations. 8

\section{References}

Bauer, A. M., \& Ellis, E. C. (2018). The Anthropocene divide: Obscuring understanding of socialenvironmental change. Current Anthropology, 59(2), 209-227. https://doi.org/10.1086/697198

Berkman, M. B., \& Plutzer, E. (2010). Evolution, creationism, and the battle to control America's classrooms. New York, NY: Cambridge University Press.

Curren, R. (2014). Judgment and the aims of education. Social Philosophy and Policy, 31(1), 36-59. https://doi.org/10.1017/S0265052514000107

Curren, R. (2018a, January 21). Living well now: What does it take? [Blog post]. Retrieved from https://www.npr.org/sections/13.7/2018/01/21/562805068/living-well-now-what-does-it-take

Curren, R. (2018b). Sustainability ethics across the curriculum. In E. E. Englehardt \& M. S. Pritchard (Eds.), Ethics across the curriculum-pedagogical perspectives (pp. 273-287). Cham: Springer. https://doi.org/10.1007/978-3-319-78939-2_17

Curren, R., \& Dorn, C. (2018). Patriotic education in a global age. Chicago, IL: University of Chicago Press.

Curren, R. R., \& Metzger, E. (2017). Living well now and in the future: Why sustainability matters. Cambridge, MA: MIT Press.

Curren, R., \& Metzger, E. (2018). The art of preserving opportunity: A response to Ferkany, Ahlberg, Macleod and Ruitenberg. Theory and Research in Education, 16(1), 113-117. https://doi.org/10.1177/1477878517727933e

Davenport, C. (2018, October 7). Major climate report describes a strong risk of crisis as early as 2040. New York Times. Retrieved from https://www.nytimes.com/2018/10/07/climate/ipcc-climate-report-2040.html

Ferkany, M. (2018). Legitimizing education in sustainability. Theory and Research in Education, 16(1), 99-103. https://doi.org/10.1177/1477878517727933a

Gershwin, L.-A. (2013). Stung! On jellyfish blooms and the future of the ocean. Chicago, IL: University of Chicago Press.

Hammer, J. (2013, June). Is a lack of water to blame for the conflict in Syria? Retrieved from https://www.smithsonianmag.com/innovation/is-a-lack-of-water-to-blame-for-the-conflict-in-syria-7 2513729/

Hickman, L. (2011, May 17). US school board teaches 'the controversy' on global warming. The Guardian. Retrieved from https://www.theguardian.com/environment/blog/2011/may/17/global-warming-school-teaching-cont roversy

Hochschild, A., \& Hochschild, D. (2018, December 29). More republicans than you think support action on climate change. New York Times. Retrieved from 
https://www.nytimes.com/2018/12/29/opinion/sunday/republicans-climate-change-polls.html Ignatieff, M. (2017). The ordinary virtues: Moral order in a divided world. Cambridge, MA: Harvard University Press.

IPCC. (2018). Global warming of $1.5^{\circ}$ C. An IPCC Special Report on the impacts of global warming of $1.5^{\circ} \mathrm{C}$ above pre-industrial levels and related global greenhouse gas emission pathways, in the context of strengthening the global response to the threat of climate change, sustainable development, and efforts to eradicate poverty. Geneva: Intergovernmental Panel on Climate Change (IPCC). Retrieved from https://www.ipcc.ch/sr15/

Jackson, C. (2018, February 18). The public mostly trusts science. So why are scientists worried? Science. https://doi.org/10.1126/science.aat3580

Kolbert, E. (2014). The sixth extinction: An unnatural history. New York, NY: Holt.

Laats, A., \& Siegel, H. (2016). Teaching evolution in a creation nation. Chicago, IL: University of Chicago Press. Retrieved from https://www.press.uchicago.edu/ucp/books/book/chicago/T/bo22541379.html

Leakey, R. E., \& Lewin, R. (1995). The sixth extinction: Patterns of life and the future of humankind. New York, NY: Doubleday.

Lewis, S. L., \& Maslin, M. A. (2018). The human planet: How we created the Anthropocene. London: Penguin.

Metzger, E. P., \& Curren, R. R. (2017). Sustainability: Why the language and ethics of sustainability matter in the geoscience classroom. Journal of Geoscience Education, 65(2), 93-100.

Numbers, R. L. (2006). The creationists: From scientific creationism to intelligent design. Cambridge, MA: Harvard University Press.

Ostrom, E. (2010). Polycentric systems for coping with collective action and global environmental change. Global Environmental Change, 20(4), 550-557. https://doi.org/10.1016/j.gloenvcha.2010.07.004

UN. (2015). Transforming our world: The 2030 agenda for sustainable development (No. A/RES/70/1). Geneva: United Nations (UN).

UNEP. (2016). Summary of the sixth global environment outlook GEO-6 regional assessments: Key findings and policy messages (No. UNEP/EA.2/INF/17). Nairobi: United Nations Environment Programme (UNEP). Retrieved from http://hdl.handle.net/20.500.11822/7644

U.S. Department of Defense. (2015, July 29). DoD releases report on security implications of climate change. Retrieved from https://dod.defense.gov/News/Article/Article/612710/dod-releases-report-on-security-implicationsof-climate-change/

WWF. (2018). Living planet report - 2018: aiming higher. Gland: World Wide Fund for Nature (WWF). Retrieved from https://s3.amazonaws.com/wwfassets/downloads/1pr2018_full_report_spreads.pdf

\section{Recommended Citation}

Curren, R. \& Metzger, E. (2019). Education in the Anthropocene: A Pragmatic Approach. On Education. Journal for Research and Debate, 2(1). https://doi.org/10.17899/on_ed.2019.4.1

\section{Download PDF version}

Do you want to comment on this article? Please send your reply to editors@oneducation.net. Replies will be processed like invited contributions. This means they will be assessed according to standard criteria of quality, relevance, and civility. Please make sure to follow editorial policies and 


\section{randall curren \& ellen metzger}

Randall Curren is Professor and Chair of Philosophy and Professor of Education at the University of Rochester (New York), and Honorary Senior Research Fellow in Education at the University of Birmingham (UK). He works primarily in philosophy of education, ethics, and moral psychology. Ellen Metzger is Professor of Geology and Science Education at San José State University, where she has co-directed the Bay Area Environmental STEM Institute since 1990. She is co-editor of a 2017 issue (vol. 65, no. 2) of the Journal of Geoscience Education on interdisciplinary teaching and sustainability.

1. For an overview of major causes and manifestations of unsustainability, see Curren and Metzger (2017, pp. 16-24). For region-by-region overviews, see UNEP (2016).

2. See IPCC (2018), and for a summary of it, Davenport (2018). Based on an analysis of 6,000 studies, it was the first systematic effort to project the impact of 2.7 degrees Fahrenheit $\left(1.5^{\circ} \mathrm{C}\right)$ of global surface mean warming. It estimated the costs of such warming at $\$ 54$ trillion and predicted severe heat waves, drought, food shortages, fires, coastal inundation, and die-offs of coral reefs (and the aquatic ecosystems they support) by 2040. To put this in perspective, global surface mean temperatures have risen from about the $+0.2^{\circ} \mathrm{C}$ to $+0.4^{\circ} \mathrm{C}$ range in the $1970 \mathrm{~s}$, to $+0.4^{\circ} \mathrm{C}$ to $+0.6^{\circ} \mathrm{C}$ in the $1980 \mathrm{~s}$, to $+0.4^{\circ} \mathrm{C}$ to $+0.8^{\circ} \mathrm{C}$ in the $1990 \mathrm{~s}$, to $+0.8^{\circ} \mathrm{C}$ to $+1.2^{\circ} \mathrm{C}$ since 2000 .

3. We define systemic action problems as collective action problems involving the management of dynamically complex systems (Curren \& Metzger, 2017, p. 129).

4. For a general account, see Lewis and Maslin (2018).

5. See Numbers (2006), and Berkman and Plutzer, (2010).

6. See Stockholm Resilience Centre, The Nine Planetary Boundaries, https://www.stockholmresilience.org/research/planetary-boundaries/planetary-boundaries/about-the-research/the-nine-plan etary-boundaries.html.

7. Cf. the educational component of the Millennium Development Goals. SDG 4, Quality Education for All, states that "education-as usual will not suffice," explaining that innovative thinking regarding the nature and purpose of education is required (UN, 2015).

8. The specific principle we defend (preservation of opportunity principle) is that "The individuals of future generations are to have prospects of living well that are as good on average as those of individuals now alive, regardless of when they are born" (Curren \& Metzger, 2017, p. 120). 